\title{
Synthesis of Connective-Tissue Components
}

\author{
THE EFFECT OF RETINOL AND HYDROCORTISONE ON CULTURED \\ LIMB-BONE RUDIMENTS
}

\author{
BY J. T. DINGLE, H. B. FELL AND J. A. LUCY \\ Strangeways Research Laboratory, Cambridge
}

(Received 9 June 1965)

\begin{abstract}
1. The action of excess of retinol on chick limb-bone rudiments cultured in chemically defined media has been investigated. 2. After 6 days in vitro, the hexosamine and hydroxyproline contents of the retinol-treated rudiments were much less than those of their paired controls. 3. Synthesis of these compounds, however, was not correspondingly decreased. 4. The control rudiments released hexosamine- and hydroxyproline-containing materials into the culture medium; a greater proportion of the hexosamine and hydroxyproline synthesized was liberated from the retinol-treated than from the control rudiments. 5. Although hydrocortisone in physiological concentrations prevented excessive hydration of the rudiments in culture, it did not significantly inhibit the changes induced by excess of retinol.
\end{abstract}

Fell \& Mellanby (1952) showed that the cartilaginous limb-bone rudiments from 7-day embryonic chicks became soft and rubbery when they were grown as organ cultures for $\mathbf{8}$ days in medium containing excess of vitamin A (10i.u./ml.). The treated rudiments were much smaller than their paired controls in normal medium, and on histological examination they were found to have lost most of the basophilic (metachromatic) material from the matrix. Subsequently Fell, Mellanby \& Pelc (1956) observed by radioautography that one of the first effects of the vitamin on cartilage was to prevent the incorporation of inorganic sulphate $\left({ }^{35} \mathrm{SO}_{4}{ }^{2-}\right)$ into the matrix; this was followed by a loss of sulphate from the matrix, which accompanied the disappearance of metachromasia in histological preparations.

In further experiments (Dingle, Lucy \& Fell, 1961) it was shown that, after 6 days' cultivation in the presence of excess of vitamin $A$, the wet and dry weights and hexosamine content of the cartilaginous rudiments were only half those of paired controls grown in normal medium, whereas the amount of DNA was $80 \%$ of that in the controls. It was clear from this result that there had been a great decrease in the material of the matrix relative to the number of cells. Evidence was obtained that this loss of intercellular material was due to the increased release of an acid protease from the lysosomes of the cells (Lucy, Dingle \& Fell, 1961; Dingle, 1961; Fell, Dingle \& Webb, 1962), the enhanced release being compensated by a greater synthesis of the enzyme (Fell \& Dingle, 1963).
Although the previous experiments demonstrated that excess of vitamin A destroys the organized structure of cartilage matrix, they shed no light on whether the vitamin also affects the synthetic activities concerned in the formation of intercellular substances. Chondrocytes might actively produce the low-molecular-weight components of matrix in the presence of excess of vitamin $A$, but be unable to form the characteristic macromolecular structures of the tissue owing to excessive proteolytic activity induced by the vitamin. We have investigated this possibility by estimating the total synthesis of two of the main constituents of the matrix, namely hexosamines and hydroxyproline, and by determining the extent to which these compounds are released into the medium. Interrelationships between the effects of vitamin A and hydrocortisone on the synthesis and release of hexosamines and hydroxyproline have also been studied, because it has been shown by Schryver (1965) that very small quantities of hydrocortisone are beneficial in maintaining organ cultures of cartilage in an apparently normal condition for 10 days.

\section{MATERIAL AND METHODS \\ Organ culture}

Explants. The humeri, femora and tibiae were removed

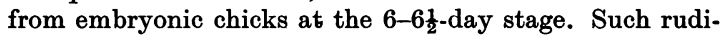
ments consist of a continuous cartilaginous rod in which the three cellular zones characteristic of ossifying cartilage are clearly differentiated as small-celled epiphysial regions at either end, adjacent intermediate zones of proliferative 
flattened cells merging with the area of hypertrophic cells that forms the middle segment of the shaft. The hypertrophic cartilage is covered by a two-layered periosteum, and the inner osteoblastic layer has deposited a thin osseous sheath on the surface of the cartilage. Embryonic chicks of the same age may vary in their degree of development, but the developmental stage of the limb-bone rudiments at explantation can be roughly assessed by the degree of calcification, as indicated by opacity to transmitted light, of the osseous collar. For this reason in each experiment the stage of calcification in the rudiments from the different chicks was recorded according to an arbitrary code, so that any variations in response due to developmental variations could be identified.

The explants included the cartilaginous 'model', the thin osseous sheath, the periosteum and a little adherent muscle; cartilage was by far the largest component.

In most of the experiments 'zero controls' were obtained by dissecting the rudiments from a number of embryos from the same batch of eggs as that used for the cultures; this material was not explanted but served as a basis of comparison with the explants.

Culture method. The culture vessels consisted of flatbottomed glass dishes $(3 \mathrm{~cm}$. diam. $\times 1 \mathrm{~cm}$. high). Each contained a square platform of stainless-steel mesh (Minimesh, F.D.P. quality, $1.5 \mathrm{~mm} . \times 0.010 \mathrm{in} . \times 0.005 \mathrm{in}$.; Expanded Metal Co. Ltd., West Hartlepool), the height of which was carefully adjusted so that the top was level with the surface of the medium. Two such vessels were enclosed in a single Petri dish $(10 \mathrm{~cm}$. diam.) carpeted with a very thin layer of absorbent cotton wool saturated with sterile $0.9 \% \mathrm{NaCl}$ solution. A large oval hole had been cut in the cotton wool to allow the culture vessels to rest on the glass floor of the Petri dish; this arrangement permitted transillumination of the rudiments when they were explanted or examined. The two culture vessels were separated by a silicone-treated glass rod whose length was about equal to the internal diameter of the Petri dish; the rod prevented any risk of fluid from the cotton wool 'creeping' between the adjacent walls of the vessels and thus contaminating the medium.

To compare the effects of two media, the two solutions were placed in a pair of culture vessels enclosed in the same Petri dish; the limb-bone rudiments from one side of an embryo were then explanted in one medium and those from the opposite side in the other. For most experiments 18 pairs of explants were grown.

The Petri dishes were stacked in small perforated-zinc and wire baskets, three to a basket, and placed in a small vacuum desiccator, which was then thoroughly gassed with $5 \% \mathrm{CO}_{2}$ in air and incubated at $38 \cdot 5^{\circ}$.

Every 2 days the media were removed from the dishes by means of Pasteur pipettes, the tips of which were bent at an angle; a separate pipette was used for each dish. The used media were collected in Bijou bottles and stored in the deep-freeze.

Fresh medium was added to each culture vessel as soon as it had been emptied, the Petri dish was placed under the dissecting binocular microscope and the explants were turned over with the aid of glass-mounted needles with an angled shaft; the Petri dishes were closed, replaced in the desiccator, regassed and returned to the incubator.

At the end of the culture period (6 days) the explants and media were collected for examination.

\section{Histology}

In nearly all the experiments two sets of explants (i.e. three pairs of rudiments) were fixed as histological controls. They were placed for $30 \mathrm{~min}$. in $3 \%(v / v)$ acetic acid in Zenker's fluid followed by $1 \frac{1}{2}-2 \mathrm{hr}$. in Zenker's fluid without acetic acid. After thorough washing in many changes of tap water, dehydration and clearing in cedar-wood oil (three lots), they were embedded in paraffin wax and serially sectioned. Preparations were stained with toluidine blue [ $30 \mathrm{~min}$. in $0.5 \%(\mathrm{w} / \mathrm{v})$ toluidine blue in $5 \%(\mathrm{v} / \mathrm{v})$ ethanol] or with Delafield's haematoxylin and chromotrop.

\section{Culture media}

In Expt. 4 medium BGJ was used. This medium was developed by Biggers, Gwatkin \& Judah (see Biggers, Gwatkin \& Heyner, 1961). In its original form medium BGJ is hyperosmotic for chicken cells and therefore for all our experiments, except Expt. 4, the $\mathrm{NaCl}$ concentration was decreased to $530 \mathrm{mg} . / 100 \mathrm{ml}$. and the $\mathrm{KCl}$ concentration to $40 \mathrm{mg} . / 100 \mathrm{ml}$. It appears, however, both from our experiments and those made by J. J. Reynolds (unpublished work), that explants grown in an osmotically modified medium are histologically indistinguishable from those in the original medium BGJ. For all our experiments $5 \mathrm{mg}$. of sodium acetate $/ 100 \mathrm{ml}$. was included in the medium, as this was found to give slightly improved results.

In previous studies the limb-bone rudiments were cultivated on a 'natural' medium containing plasma and embryo extract (cf. Dingle et al. 1961), the proteins of which presumably combined with the added retinol and thus prevented precipitation and decomposition of the vitamin. In the present experiments the use of natural media was impracticable as it contains large amounts of substances that would interfere with the estimation of hexosamine and hydroxyproline. Retinol is rapidly destroyed in saline solution containing dissolved $\mathrm{O}_{2}$ (Lucy, 1965), and it cannot be recovered from medium BGJ after $24 \mathrm{hr}$. at $37^{\circ}$; up to $60 \%$ of the vitamin may be recovered, however, when albumin, $1 \cdot 0 \%(\mathrm{w} / \mathrm{v})$, is added (Fig. 1 ). The presence of $0.5 \%$ of serum albumin allowed the recovery of about $45 \%$ of the added retinol after $24 \mathrm{hr}$., so this concentration of protein was used in the culture experiments; higher concentrations of serum proteins often had a deleterious effect on the bone rudiments. Pig $\beta$-globulin (prepared in this Laboratory) and bovine $\gamma$-globulin (Armour Pharmaceutical Co. Ltd., Eastbourne, Sussex) were used in Expts. 4 and 3 respectively; in all the other experiments bovine plasma albumin, fraction V (Armour), was employed.

Synthetic retinol (Roche Products Ltd., London) was dissolved in ethanol and then added to the medium; the same quantity of ethanol $(0.2 \%, v / v)$ was included in the control medium. Hydrocortisone sodium hemisuccinate (Solu-Cortef; Upjohn Co., Kalamazoo, Mich., U.S.A.) or Efcortalan (Glaxo Laboratories Ltd., Greenford, Middlesex) was dissolved in glass-distilled water and introduced into the medium, the same amount of water being put into the control medium.

\section{Analytical methods}

After being harvested, the rudiments were pooled in Tyrode solution, dried on filter paper and weighed. In some experiments the $\mathrm{O}_{2}$ uptake of the explants was deter- 
mined as described by Dingle et al. (1961). The bone rudiments were then dried over $\mathrm{P}_{2} \mathrm{O}_{5}$ in vacuo in the cold for 2 days and weighed again.

Subsequently the rudiments were hydrolysed in $5 \mathrm{~N}-\mathrm{HCl}$ for $4 \mathrm{hr}$. at $100^{\circ}$. This procedure was used in all analyses; no attempt was made to determine the hydrolysis conditions for optimum yields of total hexosamines since the experiments were comparative and absolute quantities were not required. Samples of used culture media and samples of unused media as reagent blanks were dried in vacuo over $\mathrm{P}_{2} \mathrm{O}_{5}$ and then hydrolysed under similar conditions. After

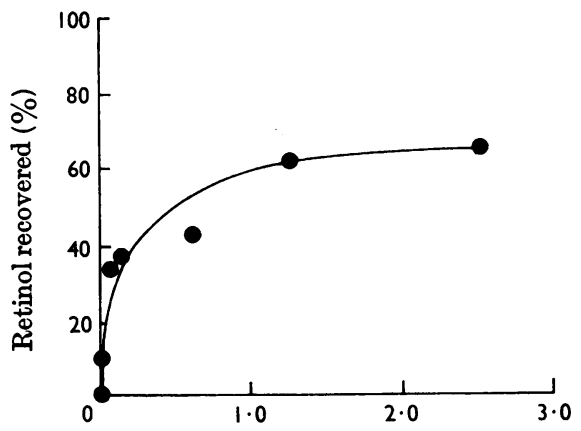

Concn. of protein in medium BGJ $(\%, w / v)$

Fig. 1. Recovery of retinol from culture medium. Retinol $(3 \mu \mathrm{g} . / \mathrm{ml}$.) was added to medium BGJ containing different concentrations of bovine albumin. The medium was incubated for $24 \mathrm{hr}$. at $37^{\circ}$ and the vitamin extracted after the addition of 1 vol. of ethanol and 2 vol. of light petroleum (b.p. $40-60^{\circ}$ ). The extraction was repeated twice and, after evaporation under $\mathrm{N}_{2}$, the retinol was assayed spectrophotometrically. hydrolysis all samples were dried over $\mathrm{P}_{2} \mathrm{O}_{5}$ and $\mathrm{KOH}$, then redissolved in water, and each sample was divided into two portions. One portion was analysed for total hexosamines by the method of Cessi \& Piliego (1960), which was used with minor technical modifications. The presence of albumin in the medium did not affect the recovery of added glucosamine. In replicate analyses of culture media to which known quantities of hexosamine hydrochloride were added $99 \%$ of the hexosamine was recovered with an accuracy of $\pm 4 \%$. Analysis of 6-day (ex ovo) rudiments, in seven groups of 12 rudiments, gave a mean hexosamine content of $130 \mu \mathrm{g} . / \mathrm{mg}$. dry wt., with a standard deviation of $24 \mu \mathrm{g} . / \mathrm{mg}$. The second portion was evaporated to dryness and then hydrolysed for $24 \mathrm{hr}$. at $110^{\circ}$ in $6 \mathrm{~N}-\mathrm{HCl}$; subsequently this hydrolysate was analysed for hydroxyproline by the procedure of Prockop \& Udenfriend (1960). The accuracy of this estimation was similar to that of the hexosamine analysis. Glucose was measured by the method of Nelson (1944).

\section{RESULTS}

Biosynthesis of hexosamine and hydroxyproline. The use of synthetic culture media has made possible the estimation of materials liberated during the growth of chick limb-bone rudiments. Untreated rudiments were found to release more than $15 \mu \mathrm{g}$. of hexosamine/rudiment after 6 days in culture; this amount was similar to that in the rudiment at the end of the experiment (Table 1). The rate of release was slightly greater towards the end of the culture period (Fig. 3). The liberation of hydroxyproline was also considerable and comparable with that contained in the rudiment (Fig. 2 and Table 1). These experiments demonstrate

\section{Table 1. Effect of retinol on the composition of cultured bone rudiments}

Humeri, femora and tibiae from 6-day embryonic chicks were grown in organ culture for 6 days on synthetic media containing protein. Eighteen pairs of rudiments were used in each experiment: one rudiment of each pair was grown in the presence of retinol. The rudiments in each group were pooled before weighing and analyses.

\begin{tabular}{|c|c|c|c|c|c|}
\hline $\begin{array}{c}\text { Expt. } \\
\text { no. }\end{array}$ & $\begin{array}{c}\text { Concn. of } \\
\text { retinol } \\
\text { (i.u./ml.) }\end{array}$ & $\begin{array}{l}\text { Wet wt. } \\
\text { (mg./bone) }\end{array}$ & $\begin{array}{c}\text { Dry wt. } \\
\text { (mg./bone) }\end{array}$ & $\begin{array}{c}\text { Hexosamine } \\
\text { ( } \mu \mathrm{g} . / \text { bone })\end{array}$ & $\begin{array}{l}\text { Hydroxy- } \\
\text { proline } \\
\text { ( } \mu \mathrm{g} . / \text { bone })\end{array}$ \\
\hline 1 & $\begin{array}{l}\mathbf{3} \\
\mathbf{0}\end{array}$ & $\begin{array}{l}1 \cdot 77 \\
3.00\end{array}$ & $\begin{array}{l}0 \cdot 193 \\
0 \cdot 273\end{array}$ & $\begin{array}{l}15 \\
17\end{array}$ & $\begin{array}{l}1 \cdot 1 \\
1 \cdot 3\end{array}$ \\
\hline 2 & $\begin{array}{l}7 \\
0\end{array}$ & $\begin{array}{l}1.72 \\
3.71\end{array}$ & $\begin{array}{l}0.093 \\
0.271\end{array}$ & $\begin{array}{l}12 \\
15\end{array}$ & $\begin{array}{l}1.0 \\
1.9\end{array}$ \\
\hline 3 & $\begin{array}{r}10 \\
0\end{array}$ & $\begin{array}{l}2 \cdot 52 \\
4 \cdot 61\end{array}$ & $\begin{array}{l}0 \cdot 166 \\
0 \cdot 206\end{array}$ & $\begin{array}{l}10 \\
30\end{array}$ & $\begin{array}{l}1 \cdot 2 \\
1 \cdot 5\end{array}$ \\
\hline 4 & $\begin{array}{r}10 \\
0\end{array}$ & $\begin{array}{l}2 \cdot 15 \\
3.95\end{array}$ & - & $\begin{array}{l}13 \\
26\end{array}$ & $\begin{array}{l}0.9 \\
1.9\end{array}$ \\
\hline 5 & $\begin{array}{r}10 \\
0\end{array}$ & $\begin{array}{l}0.71 \\
2.58\end{array}$ & $\begin{array}{l}0.075 \\
0 \cdot 189\end{array}$ & $\begin{array}{r}5 \\
10\end{array}$ & $\begin{array}{l}1 \cdot 7 \\
2 \cdot 3\end{array}$ \\
\hline $\begin{array}{c}\text { 6-day } \\
\text { (ex ovo) }\end{array}$ & - & 0.58 & 0.062 & 8 & 0.5 \\
\hline
\end{tabular}


that estimations of the synthesis of these compounds should take into account material released into the medium as well as that incorporated into the rudiment. The 'total synthesis' of any component is therefore defined in this paper as the increase in the material in the rudiment during the culture period plus the amount released into the medium at 2,4 and 6 days.

Effect of vitamin $A$. At the lowest concentration of retinol used (3i.u./ml.; Expt. 1) there was little difference in appearance between the treated and control rudiments until the fourth day, when the former had become thinner and more flexible than the latter. By the sixth day they were much smaller than the controls, and metachromasia had nearly disappeared from the shafts. Staining remained fairly intense in the relatively large epiphyses and proliferative zones, however, where the matrix had a bloated water-logged appearance. The wet weight/dry weight ratio of the controls was 11.0 and that of the treated rudiments was $9 \cdot 2$. Growth in the presence of the vitamin was inhibited (controls, $0.27 \mathrm{mg}$. dry wt./bone; treated rudiments, $0 \cdot 19 \mathrm{mg}$./bone). There was a slight increase $(7 \%)$ in the rate of release of hexosamine into the medium of the treated rudiments as compared with their paired controls, but hydroxyproline release was unaltered. A slight decrease in the hexosamine and hydroxyproline content of the rudiments was observed at the end of the culture period (Table 1). The total synthesis of hexosamines was unaffected; total hydroxyproline synthesis was slightly depressed (Table 2).

In the presence of 7 i.u. of retinol $/ \mathrm{ml}$. (Expt. 2) there was a distinct morphological effect by the second day, and at the end of the culture period the rudiments were shrunken, soft to the touch and very distorted. Metachromasia had disappeared from the shaft, and the matrix of the epiphyses had disintegrated into a loose web of metachromatic strands among which healthylooking chondrocytes were entangled. Mitosis was surprisingly abundant throughout these explants. It was common even among the former hypertrophic cells, which, as described by Fell \& Mellanby (1952), had completely lost their characteristic vacuolated structure and rounded form, and become amoeboid and basophilic. These cells proliferated to form small groups which completely filled many of the capsules that were originally occupied by single hypertrophic cells. The severity of these morphological effects was reflected in the big difference between the dry weights of the treated and control explants (Table 1). Analyses showed that in the treated rudiments the content of hydroxyproline was about half that of the controls but there was a smaller decrease in the amount of hexosamine; it is probable that in addition to these two substances other components of the tissue were also released and account for part of the difference in dry weight between the two sets of explants. It is noteworthy that the total synthesis of hexosamine and hydroxyproline was not diminished (Table 2), because although the treated rudiments contained less of these compounds than did the controls (Table 1) compensatory amounts were found in the culture medium.

The effect produced by $10 \mathrm{i} . \mathrm{u}$. of retinol $/ \mathrm{ml}$. depended on which protein was present in the medium. In Expt. 3 bovine $\gamma$-globulin was used and with this protein $10 \mathrm{i} . u$. of retinol $/ \mathrm{ml}$. had a less severe action on the rudiments than was observed with either of the two other proteins employed. Though they were considerably smaller than the controls and very flabby, the treated rudiments were larger and less distorted than the corresponding explants in the other two experiments of this group (Expts. 4 and 5). The usual changes were well advanced in the shafts of the treated rudiments but the epiphysial cartilage still retained much of its metachromatic material. Total synthesis of hexosamine (Table 2) and binding of hexosamines by the rudiments (Table 1) were both severely diminished in Expt. 3. The hydroxyproline content of the treated rudiments was less affected than the hexosamine (Table 1), but considerably more hydroxyproline was released into the medium from the treated rudiments than from the controls (Fig. 2 ) and total synthesis of the amino acid was slightly greater (Table 2).

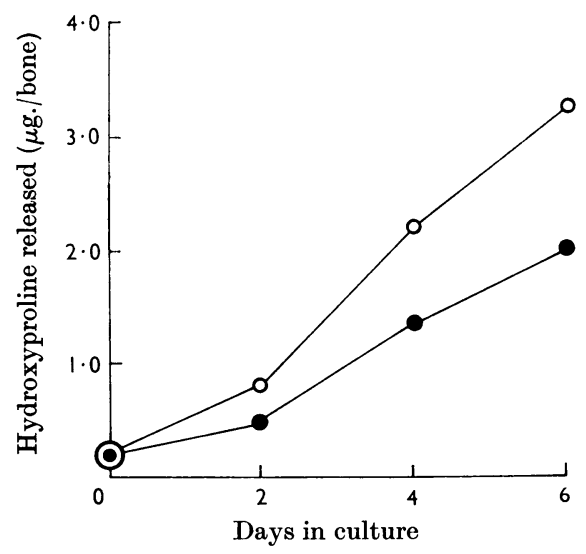

Fig. 2. Release of hydroxyproline by cultured bone rudiments. The conditions of culture were as described in Table 1. The media from 18 treated and 18 control rudiments were collected at each subculture and frozen until assayed for the hydroxyproline content. The results are expressed in $\mu \mathrm{g}$. of hydroxyproline released/rudiment. O, Retinol-treated (10i.u./ml.) cultures; •, control. 


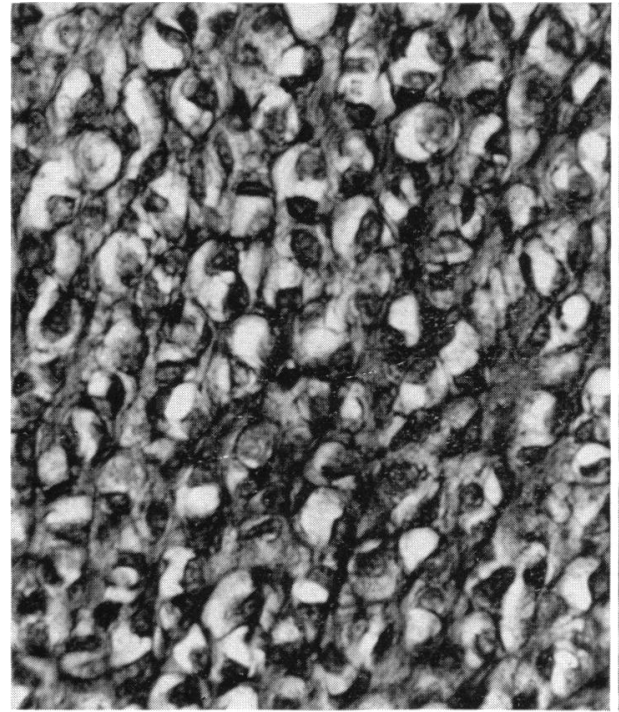

(a)

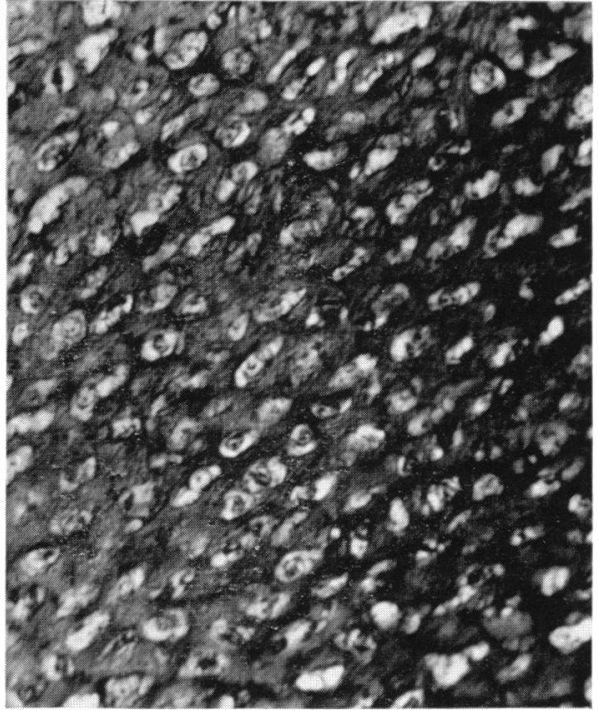

(b)

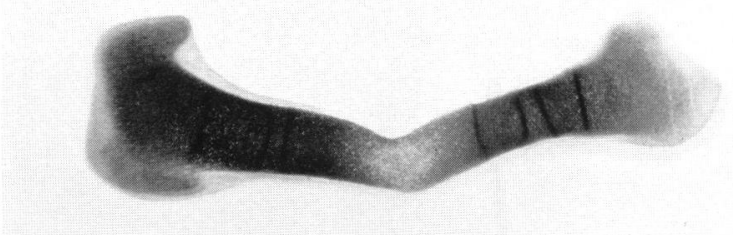

(c)

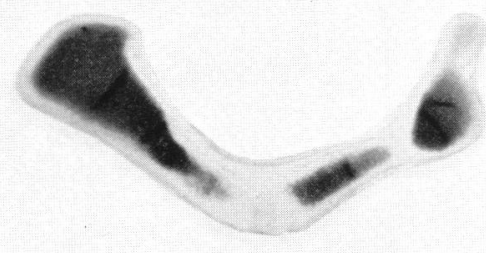

(d)

\section{EXPLANATION OF PLATE I}

All sections were stained with toluidine blue. Photographs were by M. F. Applin. (a) Distal cartilage in explanted 6-day humerus grown for 6 days in hormone-free chemically defined medium (BGJ). Foamy matrix and enlarged cavities around many of the chondrocytes are present. Magnification $\times 440$. (b) Similar region in humerus from the opposite side of the same chick used for $(a)$, after 6 days' growth in medium BGJ containing hydrocortisone $(0 \cdot 1 \mu \mathrm{g} . / \mathrm{ml}$.). The matrix appears normal. Magnification $\times 440$. (c) Control humerus grown for 6 days in the presence of hydrocortisone $(0 \cdot 1 \mu \mathrm{g} . / \mathrm{ml}$.). Magnification $\times 15$. (d) Opposite humerus from the same embryo used for $(c)$, after 6 days' cultivation in the presence of hydrocortisone $(0 \cdot 1 \mu \mathrm{g} . / \mathrm{ml}$.) and retinol $(10 \mathrm{i} . \mathrm{u} . / \mathrm{ml}$.); the explant is smaller and there is extensive loss of metachromatic material. Magnification $\times 15$. 


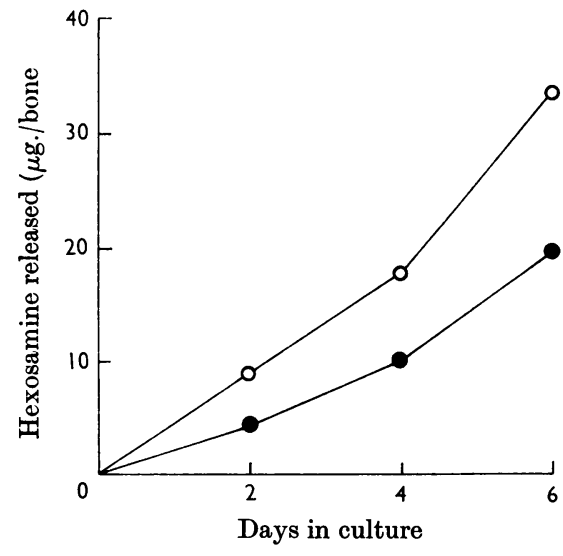

Fig. 3. Release of hexosamine by cultured bone rudiments. The conditions of culture were as described in Fig. 2. The results are expressed as $\mu \mathrm{g}$. of hexosamine released/ rudiment. $O$, Retinol-treated (10i.u./ml.) cultures; $\bullet$, control.

Pig $\beta$-globulin was used in Expt. 4. The rudiments exposed to the vitamin were more affected than those in Expt. 3, being very much smaller than the controls and very soft; many had fractures in the zones of flattened cells (cf. Fell \& Mellanby, 1952). The quantity of hexosamine bound by the treated rudiments (Table 1) was considerably less than in the controls, but the total synthesis was not inhibited (Table 2). During 6 days' cultivation the amount of hexosamine released into the medium from the treated rudiments was greater than that retained in the tissue (Fig. 3).

The most drastic changes were produced in Expt. 5 , in which the medium contained bovine serum albumin. The treated explants rapidly shrank, became grossly distorted and by the sixth day were reduced to small gelatinous nodules; the effect of the vitamin was so severe in this experiment as to inhibit the synthesis of both hexosamine and hydroxyproline (Table 2).

Effect of hydrocortisone. Schryver (1965) has shown that the excessive hydration of cartilage rudiments that occurs during cultivation in vitro (Biggers, 1963) is prevented by the presence of small quantities of hydrocortisone. This observation has been confirmed in our experiments, and further investigations have been made to see if low concentrations of hydrocortisone can prevent hydration without interfering with the synthesis of hexosamines and hydroxyproline.

Excessive hydration of cartilage rudiments grown in medium BGJ containing added protein was reflected in the wet weight/dry weight ratio, which was high compared with that of rudiments exam-
Table 2. Effect of retinol on the total synthesis of hexosamine and hydroxyproline by cultured bone rudiments

Total synthesis represents the sum of material released into the medium and that incorporated into the rudiments. The experimental conditions were as described in Table 1.

$\begin{array}{cccc}\text { Expt. no. } & \begin{array}{c}\text { Concn. of } \\ \text { retinol } \\ (\text { i.u./ml. })\end{array} & \begin{array}{c}\text { Hexosamine } \\ \text { synthesized } \\ (\mu \mathrm{g} . / \text { bone })\end{array} & \begin{array}{c}\text { Hydroxyproline } \\ \text { synthesized } \\ (\mu \mathrm{g} . / \text { bone })\end{array} \\ 1 & 3 & 28 & 1 \cdot 7 \\ & 0 & 28 & 2 \cdot 0 \\ 2 & 7 & 23 & 3 \cdot 7 \\ & 0 & 22 & 4 \cdot 0 \\ 3 & 10 & 19 & 3 \cdot 7 \\ & 0 & 39 & 3 \cdot 0 \\ 4 & 10 & 37 & - \\ & 0 & 36 & 2 \cdot 8 \\ 5 & 10 & 14 & 2 \cdot 4 \\ & 0 & 29 & 3 \cdot 7\end{array}$

ined directly ex vivo or after cultivation on natural medium. Thus the value of this ratio was 14.2 after cultivation on medium BGJ (a mean of 15 experiments each containing 15 rudiments, standard deviation 2.8 ), but only 8.8 for 6 -day rudiments $e x$ vivo (a mean of seven determinations each with 12 bones, standard deviation $1 \cdot 02$ ). A value of $10 \cdot 3$ after 6 days' cultivation on natural medium was observed in previous experiments (Dingle et al. 1961). Histological examination of rudiments grown on medium BGJ revealed that the cells in the deeper parts of the epiphyses and in the proliferative zone occupied large round cavities in a curious foamy matrix (Plate $\mathrm{l} a$ ).

Hydrocortisone was found to prevent many of these abnormalities. With $0 \cdot 1$ or $1 \cdot 0 \mu \mathrm{g}$. of the hormone $/ \mathrm{ml}$. the matrix of the rudiments was much denser than in the controls (Plate $1 b$ ). The foamy appearance characteristic of the control explants was observed only near the articular surfaces and sometimes in limited patches in the zone of flattened cells; the chondrocytes were closely embedded in the matrix. The dry weight of the cultured rudiments was unaffected by concentrations of hydrocortisone below $1.0 \mu \mathrm{g} . / \mathrm{ml}$. but the wet weight was decreased by even the lowest concentration tested (Table 3). A mean value of 8.0 was obtained for the wet weight/dry weight ratio in five experiments (each with 15 rudiments) in which the concentration of hydrocortisone did not exceed $0 \cdot 1 \mu \mathrm{g} . / \mathrm{ml}$.

With $1 \mu \mathrm{g}$. of hydrocortisone $/ \mathrm{ml}$. the hydroxyproline content of the rudiments was depressed, but with lower concentrations the hydroxyproline was increased (Table 3). This increase was due to 
Table 3. Effect of hydrocortisone on the composition of cultured bone rudiments

The experimental conditions were as described in Table 1, except that one rudiment of each pair was cultivated in the presence of hydrocortisone.

\begin{tabular}{|c|c|c|c|c|c|}
\hline $\begin{array}{l}\text { Concn. of } \\
\text { hydro- } \\
\text { cortisone } \\
(\mu \mathrm{g} . / \mathrm{ml} .)\end{array}$ & $\begin{array}{l}\text { No. of } \\
\text { rudiments }\end{array}$ & $\begin{array}{l}\text { Wet wt. } \\
\text { (mg./bone) }\end{array}$ & $\begin{array}{l}\text { Dry wt. } \\
\text { (mg./bone) }\end{array}$ & $\begin{array}{c}\text { Hexosamine } \\
\text { ( } \mu \mathrm{g} . / \text { bone })\end{array}$ & $\begin{array}{l}\text { Hydroxy- } \\
\text { proline } \\
\text { ( } \mu \text { g./bone) }\end{array}$ \\
\hline $\begin{array}{l}1 \cdot 0 \\
0 \cdot 0\end{array}$ & $\begin{array}{l}15 \\
15\end{array}$ & $\begin{array}{l}2 \cdot 50 \\
5 \cdot 00\end{array}$ & $\begin{array}{l}0 \cdot 240 \\
0 \cdot 353\end{array}$ & $\begin{array}{l}23 \\
30\end{array}$ & $\begin{array}{l}1 \cdot 9 \\
2 \cdot 3\end{array}$ \\
\hline $\begin{array}{l}0 \cdot 1 \\
0 \cdot 0\end{array}$ & $\begin{array}{l}30 \\
30\end{array}$ & $\begin{array}{l}2 \cdot 30 \\
3 \cdot 93\end{array}$ & $\begin{array}{l}0 \cdot 278 \\
0 \cdot 273\end{array}$ & $\begin{array}{l}16 \\
16\end{array}$ & $\begin{array}{l}3 \cdot 1 \\
1 \cdot 3\end{array}$ \\
\hline $\begin{array}{l}0.01 \\
0.00\end{array}$ & $\begin{array}{l}45 \\
45\end{array}$ & $\begin{array}{l}2 \cdot 89 \\
4 \cdot 71\end{array}$ & $\begin{array}{l}0 \cdot 380 \\
0 \cdot 388\end{array}$ & $\begin{array}{l}26 \\
30\end{array}$ & $\begin{array}{l}3 \cdot 0 \\
1 \cdot 5\end{array}$ \\
\hline $\begin{array}{l}\text { 6-day } \\
(\text { ex ovo })\end{array}$ & 48 & 0.75 & 0.088 & 9 & $0 \cdot 6$ \\
\hline
\end{tabular}

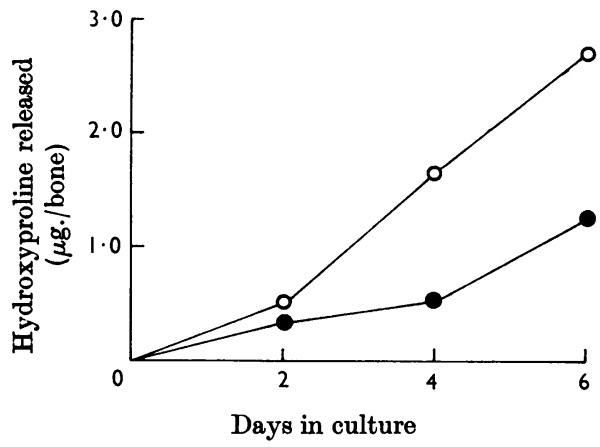

Fig. 4. Effect of hydrocortisone on the release of hydroxyproline by cultured bone rudiments. Eighteen paired rudiments were grown for 6 days on medium containing bovine serum albumin. One rudiment of each pair was grown on medium containing $0 \cdot 1 \mu \mathrm{g}$. of hydrocortisone $/ \mathrm{ml}$. The hydroxyproline release was measured as described in Fig. 2. $\mathrm{O}$, Control; ๑, hydrocortisone $(0 \cdot 1 \mu \mathrm{g} . / \mathrm{ml}$.) added.

inhibition of the release of hydroxyproline into the culture medium (Fig. 4) combined with a small rise in the total synthesis of the imino acid (Table 4).

Release of hexosamines from the rudiments into the medium was also inhibited by hydrocortisone (Fig. 5), but this did not result in an increased quantity in the rudiments (Table 3) since total synthesis of hexosamines was depressed by the hormone at all the concentrations tested (Table 4). The depression of synthesis might perhaps be related to a small inhibition of glucose utilization $(14 \%)$, and also to a slight inhibition of oxygen uptake, that were observed after the rudiments had been cultured for 6 days. In two experiments each on 15 pairs of rudiments, the mean rate of oxygen uptake without hydrocortisone was $1 \cdot 6 \mu l$./
Table 4. Effect of hydrocortisone on the total synthesis of hexosamine and hydroxyproline by cultured bone rudiments

Total synthesis represents the sum of material released into the medium and that incorporated into the rudiments. The experimental conditions were as described in Table 1 , except that one rudiment of each pair was cultured in the presence of hydrocortisone.

$\begin{array}{cccc}\begin{array}{c}\text { Concn. of } \\ \text { hydro- } \\ \text { cortisone } \\ (\mu \mathrm{g} . / \mathrm{ml} .)\end{array} & \begin{array}{c}\text { No. of } \\ \text { rudiments }\end{array} & \begin{array}{c}\text { Hexosamine } \\ (\mu \mathrm{g} . / \mathrm{bone})\end{array} & \begin{array}{c}\text { Hydroxy- } \\ \text { proline } \\ (\mu \mathrm{g} . / \mathrm{bone})\end{array} \\ 1.0 & 15 & 34 & 2.9 \\ 0.0 & 15 & 47 & 3 \cdot 6 \\ 0.1 & 30 & 25 & 3.9 \\ 0.0 & 30 & 34 & 3 \cdot 3 \\ 0.01 & 30 & 38 & 4.7 \\ 0.00 & 30 & 44 & 3 \cdot 1\end{array}$

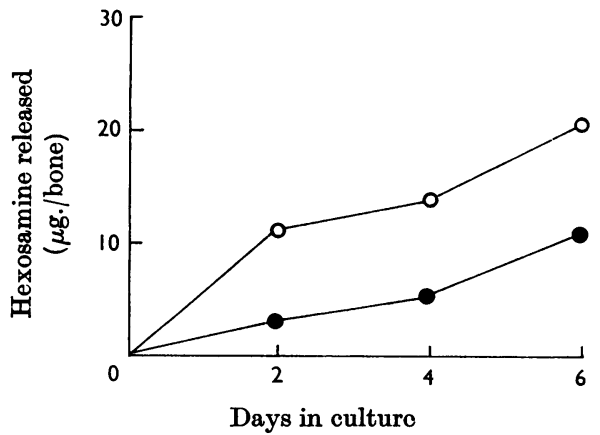

Fig. 5. Effect of hydrocortisone on the release of hexosamine by cultured bone rudiments. The conditions were as described in Fig. 4. O, Control; $\bullet$, hydrocortisone (0.1 $\mu$ g./ ml.) added. 
Table 5. Effect of vitamin $A$ on the synthesis of hexosamine and hydroxyproline by cultured bone rudiments in the presence of hydrocortisone

The experimental conditions were as described in Table 1, except that both the control and experimental media contained hydrocortisone.

\begin{tabular}{|c|c|c|c|c|c|c|}
\hline \multirow[b]{2}{*}{ Expt. no. } & \multirow{2}{*}{$\begin{array}{c}\text { Concn. of } \\
\text { retinol } \\
\text { (i.u./ml.) }\end{array}$} & \multirow{2}{*}{$\begin{array}{c}\text { Concn. of } \\
\text { hydro- } \\
\text { cortisone } \\
(\mu \mathrm{g} . / \mathrm{ml} .)\end{array}$} & \multicolumn{2}{|c|}{ Hexosamine ( $\mu \mathrm{g} . /$ bone) } & \multicolumn{2}{|c|}{ Hydroxyproline ( $\mu \mathrm{g} \cdot /$ bone) } \\
\hline & & & $\underset{\text { In }}{\text { medium }}$ & $\underset{\text { rudiments }}{\text { In }}$ & $\underset{\text { medium }}{\text { In }}$ & $\underset{\text { rudiments }}{\text { In }}$ \\
\hline 6 & $\begin{array}{r}10 \\
0\end{array}$ & $\begin{array}{l}0 \cdot 1 \\
0 \cdot 1\end{array}$ & $\begin{array}{r}12 \\
7\end{array}$ & $\begin{array}{l}10 \\
18\end{array}$ & $\begin{array}{l}1.9 \\
1.0\end{array}$ & $\begin{array}{l}2 \cdot 1 \\
2 \cdot 6\end{array}$ \\
\hline 7 & $\begin{array}{r}10 \\
0\end{array}$ & $\begin{array}{l}0.01 \\
0.01\end{array}$ & $\begin{array}{l}16 \\
11\end{array}$ & $\begin{array}{l}13 \\
20\end{array}$ & $\begin{array}{l}1 \cdot 9 \\
1 \cdot 1\end{array}$ & $\begin{array}{l}1.0 \\
1.9\end{array}$ \\
\hline 8 & $\begin{array}{l}5 \\
0\end{array}$ & $\begin{array}{l}0.1 \\
0.1\end{array}$ & $\begin{array}{l}18 \\
11\end{array}$ & $\begin{array}{l}18 \\
28\end{array}$ & $\begin{array}{l}2 \cdot 8 \\
2 \cdot 5\end{array}$ & $\begin{array}{l}3 \cdot 8 \\
4 \cdot 5\end{array}$ \\
\hline
\end{tabular}

hr./explant, whereas with the paired rudiments grown in the presence of $0 \cdot 1 \mu \mathrm{g}$. of hydrocortisone/ ml., the corresponding value was $1 \cdot 26 \mu \mathrm{l} . / \mathrm{hr} . /$ explant.

Combined effects of vitamin $A$ and hydrocortisone. In Expt. 6 (in Table 5) $0 \cdot 1 \mu \mathrm{g}$. of hydrocortisone $/ \mathrm{ml}$. was found to have some inhibitory influence on the effect of $10 \mathrm{i}$.u of the vitamin/ml., but the changes produced by the latter agent were well marked though not extreme. The A-hypervitaminotic explants (Plate 1c) were much smaller than their paired controls (Plate $1 d$ ), but were neither fractured nor greatly distorted. Metachromasia largely disappeared from a fairly wide superficial zone and was greatly diminished throughout the middle segment of the shaft. Much metachromatically staining matrix remained in the ends of the explants, however, and had the dense uniform appearance characteristic of that in the (hydrocortisonetreated) controls. The vitamin had its characteristic effect in depressing the amount of hexosamine and hydroxyproline in the rudiment and increasing that in the medium, while the total synthesis was little affected (Table 5).

The rudiments of Expt. 7 were grown in the same medium but with the addition of only $0.01 \mu \mathrm{g}$. of hydrocortisone/ml. Vitamin A (10i.u./ml.) produced much more drastic changes than in the previous experiment. The explants developed fractures and became very flabby. Sections showed extensive loss of metachromasia throughout the cartilage; the remaining metachromatic matrix was less dense and much less heavily stained than in Expt. 6. The matrix of the controls also stained less intensely with toluidine blue than in the previous experiment, and especially in the zones of flattened cells there were signs of some excessive hydration, though less than in controls grown in hormone-free medium. The more drastic histological action in this experiment was not reflected in a greater loss of hexosamine, although there was slightly more effect on the hydroxyproline content than in Expt. 6. The total synthesis of these compounds was not affected by the severe action of the vitamin (Table 5).

The characteristic effects of the vitamin on the components of the matrix were still apparent at 5i.u./ml. in the presence of $0 \cdot 1 \mu \mathrm{g}$. of hydrocortisone/ ml. (Expt. 8 in Table 5).

\section{DISCUSSION}

In previous studies, it was found that after 6 days' cultivation on a natural medium containing added vitamin A (10i.u./ml.) the amino sugar content of cartilaginous limb-bone rudiments was half that of the control rudiments (Dingle et al. 1961). This observation has been confirmed in the present investigation in which a synthetic medium has been used. The experiments described in the present paper have shown also that, if the effect of vitamin A on embryonic cartilage is not too severe, the total synthesis of hexosamine and hydroxyproline is not diminished but that, as compared with controls, a greater proportion of both these substances is shed into the medium. This is consistent with the observation by Fell et al. (1956) that one of the first effects of excess of vitamin $A$ on cartilage is a decreased incorporation of inorganic sulphate into the intercellular material.

It was surprising to find that the untreated explants cultured on medium BGJ shed considerable quantities of both amino sugars and hydroxyproline into the culture medium. Hydrocortisone, in physiological concentrations, decreased the amount liberated and, for hydroxyproline, correspondingly raised that in the tissue, but the release remained fairly high. Whether this liberation of hexosamines and hydroxyproline is a normal feature of growing cartilage or a peculiarity of organ cultures is not 
known. Neither is it known what the hexosamineand hydroxyproline-containing compounds are, since both of these substances were assayed after acid hydrolysis of the medium. From preliminary work, however, it appears that the hydroxyprolinecontaining material is of low molecular weight, because over $90 \%$ of the hydroxyproline released into the medium by control cultures is diffusible. Jasin, Fink, Wise \& Ziff (1962) found that in growing but not in adult animals hydroxyproline is present in the blood. It seems possible that this imino acid may normally be shed from connective tissue during growth, but as yet its source in vivo is not known. J. J. Reynolds (personal communication), in experiments with protein-free synthetic media, has confirmed that hydroxyproline is liberated into the medium from 7-day rudiments in untreated cultures, but he found little release of hexosamine. The 6-day rudiments used in our experiments had a dry weight of about $0.07 \mathrm{mg}$. bone, a hydroxyproline content of $0 \cdot 5-0 \cdot 6 \mu \mathrm{g}$./bone and a hexosamine/hydroxyproline ratio $13 \cdot 0$. In contrast, the 7-day rudiments used by Reynolds were nearly 3 times as heavy, contained $1.4 \mu \mathrm{g}$. of hydroxyproline/bone and had a hexosamine/ hydroxyproline ratio $5 \cdot 0$. It is thought that the relatively high proportion of hexosamine in the 6-day rudiments may be associated with a period of active synthesis of this component, and that this may account for the release of a relatively large amount of hexosamine into the culture medium in our experiments.

Even with relatively toxic doses of retinol the total synthesis of hexosamine and hydroxyproline was found to be considerable although it was less than in the control cultures. Thus it appears that the activation of lysosomes, release of acid hydrolases and consequent degradation of connectivetissue matrix that occur under the influence of excess of retinol do not grossly inhibit the synthesis of certain constituents of cartilage matrix. The results of the present investigations are therefore not inconsistent with the observations of Wolf \& Varandani (1960), which suggested that vitamin A plays a role in the biosynthesis of polysaccharides. Since synthesis and degradation may occur simultaneously in hypervitaminosis, the net result will depend on the relative rates of the two processes. Thus when high concentrations of retinol (10i.u./ ml.) are used, which not only release lysosomal enzymes but also inhibit synthesis of connectivetissue components, a drastic breakdown of cartilage matrix is observed. Differences between the synthetic activities of the epiphyses and the shaft may explain the regional effects of the vitamin. Both in untreated explants in culture (Fell et al. 1956) and in the normal embryo (Amprino, 1954) the diaphysial cartilage rapidly loses its capacity to incorporate ${ }^{35} \mathrm{SO}_{4}{ }^{2-}$, which continues to be actively bound by the epiphyses and proliferative zones; it is significant that the shaft is the first region to lose its metachromasia in response to vitamin A.

The balance between the synthesis and degradation of connective tissues may be disturbed not only by factors influencing synthesis but also by variations in the rate of degradation. The latter process might be affected by differences in the activities of lysosomal enzymes and by factors controlling the release of these enzymes from the lysosomal particles. For example, inhibition of lysosomal protease by $\epsilon$-aminohexanoic acid (Ali, 1964) largely prevents the breakdown in vitro of the matrix of retinol-treated cartilage $(H$. B. Fell \& J. T. Dingle, unpublished work). Further, hydrocortisone, at relatively high concentrations $(7 \cdot 5 \mu \mathrm{g}$./ ml.), retards the action of excess of vitamin A on embryonic cartilage in culture (Fell \& Thomas, 1961); as hydrocortisone stabilizes lysosomal membranes exposed to damaging agents (Weissman \& Dingle, 1961 ; Weiss \& Dingle, 1964), it seems possible that the steroid diminishes the rate of degradation of cartilage matrix by inhibiting the release of lysosomal enzymes.

In contrast with the action of hydrocortisone in high concentrations the physiological quantities of the hormone used in the present experiments did not materially affect the action of excess of retinol on the limb-bone rudiments. Schryver (1965) has shown that low doses of hydrocortisone prevent the abnormal hydration of cartilage grown in chemically defined media that was observed by Biggers (1963). We have confirmed both these findings, but no satisfactory explanation of this action of hydrocortisone is yet available. Our observations suggest that hydrocortisone, at a physiological concentration, may be a desirable component of chemically defined media in biochemical studies on the action of other physiologically active compounds.

H. B. F. is a Royal Society Research Professor. J. T. D. and J. A. L. are members of the Medical Research Council's external staff.

\section{REFERENCES}

Ali, S. Y. (1964). Biochem. J. 93, 611. Amprino, R. (1954). R.C. Accad. Lincei, Ser. 8, 16, 781. Biggers, J. D. (1963). Monogr. nat. Cancer Inst. 11, 1.

Biggers, J. D., Gwatkin, R. B. L. \& Heyner, S. (1961). Exp. Cell Res. 25, 41.

Cessi, C. \& Piliego, F. (1960). Biochem.J. 77, 508.

Dingle, J. T. (1961). Biochem. J. 79, 509.

Dingle, J. T., Lucy, J. A. \& Fell, H. B. (1961). Biochem. J. 79, 497.

Fell, H. B. \& Dingle, J. T. (1963). Biochem. J. 87, 403.

Fell, H. B., Dingle, J. T. \& Webb, M. (1962). Biochem. J. 83, 63. 
Fell, H. B. \& Mellanby, E. (1952). J. Physiol. 116, 320.

Fell, H. B., Mellanby, E. \& Pelc, S. R. (1956). J. Physiol. 133, 89.

Fell, H. B. \& Thomas, L. (1961). J. exp. Med. 114, 343.

Jasin, H. E., Fink, C. W., Wise, W. \& Ziff, M. (1962). J. clin. Invest. 41, 1928.

Lucy, J. A. (1965). Biochem. J. 96, 12 P.

Lucy, J. A., Dingle, J. T. \& Fell, H. B. (1961). Biochem.J. 79,500 .
Nelson, N. (1944). J. biol. Chem. 153, 375.

Prockop, D. J. \& Udenfriend, S. (1960). Analyt. Biochem. 1, 228.

Schryver, H. F. (1965). Exp. Cell Res. 37, 327.

Weiss, L. \& Dingle, J. T. (1964). Ann. Rheum. Dis. 23, 57. Weissmann, G. \& Dingle, J. T. (1961). Exp. Cell Res. 25, 207.

Wolf, G. \& Varandani, P. T. (1960). Biochim. biophys. Acta, 43, 501 . 